Ye. M. Lebid-Hrebenyuk, PhD, Senior Research Fellow,

Shevchenko Institute of Literature

of the National Academy of Sciences of Ukraine, Kyiv

\title{
GENERAL CONTENTS AND PROBLEMS OF THE DIARY OF THE XIX CENTURY LITERATORS
}

The article is devoted to research of specific genre of diary in creative heritage of P. Kulish, O. Nikitenko and T. Shevchenko. Intraliterary comparative analysis allowed to comprehend nature of genre and to define his basic characteristics. The special attention is spared to the general moments in diaries language, orientation on a future reader, atmosphere of "expectation". In the diaries the author acts as a part of the action, moreover, he is the hero of the story, it is therefore obvious that description of all adventures are typically narrated from the author's perspective so the author and the narrator merge-and the narrative adopts a first person narrative. The communicative techniques in the structure of the text are described briefly-implicit comparative studies, evaluative judgments, creation of the image of a stranger, "other", address to the reader, etc. Also are comprehended separate theses about correlation of looks of writers on religion, friendship, the phenomenon of silence in the text. The multidimensional character of silence opens up, the specific of silence (silence's philosophical potential) in text: variants of literary pausing/silence can be found throughout diary, they are expressed by several types of figures of silence. The meaning of silence shifts according to its context in diary. The especially interesting discoveries are based on general moments in both diaries - critical thinking, engaging the reader in the text, deep existential thoughts, digression (partial retreat from a main theme in text). Comparison of texts of diaries gives an opportunity to trace an origin, forming, statement in Ukrainian literature of such variety of diary as a writer.

Keywords: diary, genre, narrative, idiostyle, recipient, author's intention.

\section{УДК 821.161.2.Куліш}

С. В. Ленська, д-р філол. наук, доц., Полтавський національний педагогічний університет імені В. Г. Короленка, Полтава

\section{ОСОБЛИВОСТІ ПОЕТИКИ ОПОВІДАННЯ П. КУЛІША "ГОРДОВИТА ПАРА"}

Оповідання П. Куліша "Гордовита пара" розглянуто в контексті романтичної традиції. Однак сюжет, основні мотиви, образи-персонажі твору, мовленнєва організація тексту переконують у тому, щзо в поетиці переплітаються елементи романтизму і сентименталізму.

Ключові слова: оповідання, романтизм, сентименталізм, балада, портрет, оповідач, психологізм. 
Твір "Гордовита пара (Бабусине оповідання)" П. Куліша був опублікований у журналі "Основа" 1861 р. під псевдонімом Петро Забоцень, а через рік вийшов окремим виданням.

У низці досліджень останніх років (праці Ж. Янковської, Ліша Сюй, Н. Романишин та ін.) оповідання розглядається у контексті романтичного дискурсу. Однак не все так однозначно. Тож метою нашої розвідки $є$ з'ясування поетики твору і визначення рис романтизму й сентименталізму в ньому.

Сюжет твору простий: багата красуня, донька отаманасічовика Маруся Ковбанівна покохала нерівню - бідного козака Прохора Осауленка. Між ними спалахнуло взаємне почуття. Але несподівано для всіх юнак заслав старостів до вбогої сироти Оринки. Тяжко переживаючи зраду, Маруся подала рушники закоханому в неї сотникові Байдакові. Вінчання обох пар відбулося разом, але щастя їм не принесло: незабаром гірко засумував за Марусею Прохор, а молода дружина сотника збожеволіла. Кінцівка оповідання романтична ітрагічна: "[...] ідуть наші селяни через греблю до церкви, аж дивляться: на стрижні Осауленкова шапка плаває. [...] Закинули невід. - Так і єсть! Витягли їх у парі. Обнявшись, вони в воді лежали. [...] Над ставом, поміж вербами й поховали їх у одній домовині" [Куліш, 1989, с. 183].

Основна тема твору - кохання. Воно було взаємним, але 3 невідомих причин пара розпалася: "Осауленкові, як він іще залицявсь до Марусі чи любився з нею, просто сказати, - здалось, що вона, Маруся, краса мальована, багатирка пишна, що вона ним гордує, що вона 3 милості ніби тільки до його свою вквітчану, золотом повиту голову схиляє. Бог їх знає, яке там слово між ними бовкнуло, тільки він засумував тяжко, трохи, кажуть, сам собі смерті не заподіяв, а далі - постривай же - взяв та й прихиливсь до вбогої сироти, Орини безталанної! А та собі постривай же! - та й переказала сотникові: приїзди за рушником" [Куліш, 1989, с. 187]. Слід наголосити, що мотивація вчинків героїв подана з точки зору наратора - старої бабусі, яка згадує часи молодості своєї баби. Звісно, минуло чимало часу з моменту подій, оповідачка не була присутньою під час побачень закоханих, тому iii інтерпретація зводиться до традиційного 
мотиву "люди розлучили". У наведеному уривкові наголошується на гордості Марусі. Ця риса засуджується нараторкою, що цілком уписується у християнський етичний канон, де гордість - один із смертних гріхів.

Непорозуміння між закоханими героями призвело до розлуки, а потім і до смерті обох. Дослідники недооцінюють роль другорядної героїні, "вбогої сироти Орини", яка прискорила сватання сотника Байдака до Марусі, тим самим забезпечивши собі заміжжя з красенем Осауленком. Негідний учинок дівчини не приніс їй жаданого щастя, адже швидко Прохор "засумував же тяжко", "занудив світом несказанно. 3 лиця спав, аж почорнів од великої туги, і все в пасіці з дідом пасічником сидить", "все мовчки плаче, а вночі встане і навкруги пасіки, мов неприкаяний, блукає". Стан головного героя змальований прийомом зовнішнього психологізму: "Він і діло робить, і нікому важкого слова не скаже, і богу молиться, тільки знай мовчить, та сумує, та чахне, мов свічка тане" [Куліш, 1989, с. 188].

Наведені цитати мимоволі нагадують стан головного героя Василя після смерті коханої у повісті Г. Квітки-Основ'яненка "Маруся". Він також "богу молився", постригся у ченці, служив у монастирі, але не зміг жити без своєї Марусі й помер із туги. Ця типологічна схожість змушує думати про риси сентименталізму в оповіданні П. Куліша.

Промовистими $є$ також інші деталі твору. Насамперед те, що сотник Байдак, "удівець був і бездітний, а грошей сила" [Куліш, 1989 , с. 184], посватався до Марусі, знаючи, що вона любить іншого. Після вінчання Маруся невдовзі збожеволіла, ходила по селу уквітчана сухими васильками та чорнобривцями. Чоловік забирав іiі на хутір, куди перевіз після весілля і тещу, але вона знову з'являлася в селі: "Осауленко наче ждав іiі, - вийшов назустріч. Побачив - і заридав, як мала дитина. [...] Що то були за жалощі! Краса іiі не змінилась, личко горить, очиці сяють, та страшно було на неї дивитись". Сентименталізм, як відомо, апелював до перебільшених людських почуттів, пробуджував у читачів співчуття. Це вповні виявляється у поведінці Прохора: "Вийшла й нещасна Орина 3 хати, нічого й не каже, і чоловіка свого не впиняє, а той аж у сиру землю б'ється" [Куліш, 1989, 
c. 187]. Отже, взаємне почуття між Марусею і Прохором уже після весілля не засуджується їхніми вінчаними чоловіком i жінкою, що відбувається всупереч народним звичаям i християнській етичній традиції, оскільки кохання ставиться автором вище за все - за людські та Божі закони. Це також свідчить на користь не тільки романтичній традиції, але й етиці сентименталізму.

Що відбувалося між головними героями потім, як вони опинилися в греблі, залишається невідомим. Але та обставина, що вони знайдені в обіймах одне одного і поховані в одній домовині, свідчить про сентиментальне перебільшення. Навряд чи рідні дозволили б це насправді. П. Куліш малює такий собі український сюжет про Ромео і Джульєтту: "Нехай їх уже Господь хоч на тім світі не розлучає!" [Куліш, 1989, с. 188]. Подібними є і останні рядки "Марусі" Г. Квітки-Основ'яненка: "Довго, довго стояв Наум над гробом його!.. Далі здихнув, перехрестився і каже: - Дай, Господи милосердний, щоб ти там знайшов свою Марусю!.." [Квітка-Основ'яненко, 2003, с. 116].

Наголосимо ще на одній деталі. Маруся була дуже багатою, а Прохор - бідним. Подібна сюжетна ситуація описана і у повісті "Маруся" Г. Квітки-Основ'яненка. Майнова нерівність не стає на заваді щастю, адже людські почуття не мають станових меж. М. Карамзін у своій сентиментальній повісті "Бідна Ліза" проголосив: "і селянки любити вміють", тобто будь-яка матеріальна нерівність не може стати на заваді людському самовиявленню і коханню зокрема.

Як відомо, серед ознак сентименталізму дослідники виокремлюють такі: "утвердження чуттєвої, ірраціональної стихії в художній творчості, протиставлене суворим, раціоналістичним нормативам класицизму та властивому добі Просвітництва культу абсолютизованого розуму" [Літературознавча енциклопедія, 2007, т. 2, с. 381], "зосередження уваги на внутрішньому світі людини, перебільшених почуттях, відстоювання свободи пристрастей; завдання літератури - збуджувати у читача глибокі переживання, схвильованість, щоб у такий спосіб сприяти збагаченню його духовного світу [...]", ушляхетнювати його душу. У сентиментальних творах зазвичай зображувалися події, які мають "зворушити 
читача: нещасливе кохання, утиски і переслідування героя, страждання самотньої людини, нерідко - смерть" [Пахаренко, 2004, с. 195]. Тому в сентименталізмі з'явилися мотиви, які потім широко використовувалися романтиками: кохання 3 першого погляду, передчасна смерть від туги, розлука тощо.

Прийом гіперболізації стосується характерологічної риси Марусі Ковбанівни - оповідачка кілька разів наголошує на гордій красі дівчини. Саме гордість стала на заваді взаємному щастю, вона ж винесена у заголовок твору. "До неї й приступити, каже, було страшно: така велична. [...] I козаки-молодики іiі жахались, не то що. Очима поводить - наче душу з тебе виймає: все б їй розказав, не потаїв би й гріха перед нею. Владична, справді, каже, владична була краса в Ковбанівни" [Куліш, 1989, с. 182]. "Скине оком - наче до тебе заговорить, а заговорить - наче заграє. Який би то і козак був, щоб до неї з жартами, з прикладками! Такого не було й на всій Гетьманщині, здавалось". І ось така пишна красуня покохала простого козака, "щиру душу", "мов та хмелина коло його в'ється" [Куліш, 1989, с. 183]. Але непорозуміння між закоханими призвело до трагічної розв'язки. Нараторка вживає зменшено-пестливі форми слів, звертаючись до Марусі й Прохора - "мої безталанночки" [Куліш, 1989, с. 187].

У традиції сентименталізму автор детально портретує свою героїню, детально описує їі одяг: "Кунтуш на їй - самі златоглави, коралі на їй - усі в дукачах" [Куліш, 1989, с. 182]; "I в будень було дукачі носить; стане проти сонця - королівна, та й годі!". "У неділю, було, зайдемо до старої Ковбанихи, то й Маруся, вернувшись із церкви, увійде в світлицю та, не скидавши блават своїх і золотого дівоцького кораблика, так і сяде коло віконця. Сонечко вдарить по тих дукачах препишних, по тому брузументі суто золотому - сяє Маруся - квітка квіткою!" [Куліш, 1989, c. 184]; "Вся в золоті, в шовках. Там одна плахта - павине перо пар двох волів чумацьких стоїла, а коралям і ціни нема. А сукня ж то з золотими усами!" [Куліш, 1989, с. 185]. Докладний опис убрання Марусі дещо нагадує портрет іншої Марусі - героїні Г. Квітки-Основ'яненка.

Фольклорна основа притаманна i сентименталізмові, i романтизмові. Детальніше цей аспект висвітлено в дослідженнях 
Жанни Янковської і Ліша Сюй. Оповідання "Горовита пара", на думку Ліша Сюй, репрезентує "психологічно-особистісну" стильову течію в українському романтизмі [Сюй Ліша, 2015, с. 8].

У тексті наведено фрагмент сімейно-обрядового дійства весілля: дівич-вечір збирала Орина Лободівна, але Маруся перевершила суперницю пишними напоями; вінчання відбувалося на дві пари: "Що ж то за весілля скоїлось, то й сказати не можна! Уся сотня гуляла три дні і три ночі; самих порохів дві мірки вистреляли. Гармати до вдовиної хати попривозили. Родичі молодої 3 гармат у воротях стріляли, а козацтво знов 3 гарматами та 30 самопалами молодої добувало. [...] А як до вінця їхали, то - господе мій! - вісьмерик волів з Піжмурок пригнали, таких, що кожна пара незчисленні гроші коштує. [...] Та ще привезли якогось німецького воза, довжелезного, що й у дворі не зміститься, та того воза самими киндяками й вислали, аж по люшнях, по колесах теліпається, на війя киндяк лягає, а волам роги, як те вильце, червоними та блакитними широченними стрічками ввили, вінки з дубового листу та з золотих гвоздиків на шиї волам повішали" [Куліш, 1989, с. 186].

Під час вінчання Маруся стала "ще лучча, ще краща", "очі сіяють, як зорі". "А Осауленкові було якось ніяково" [Куліш, 1989, с. 186]. Гордість розлучила закоханих, а смерть поєднала.

На своєрідність наративної структури оповідання вказує підзаголовок - "бабусине оповідання". Оповідачка, стара бабуся, розповідає онукам про бувальщину за часів своєї бабці: "Древня була моя бабуся-покійничка, - ще то з тих старосвітських людей, що шведчину й усякі невпокої козацькі своїми очима бачили. [...] Козаки були козаками, дітоньки - одно слово: скрізь пахло волею; земля була розкішна; риби в воді, звіря в гаях - аби охота ловити; і трави були буйніші; здається, й сонце сіяло краще на святому небові..." [Куліш, 1989, с. 182].

Як слушно зазначає Ж. Янковська, "введення в текст таких підзаголовків чи зауважень від особи оповідача передбачає не лише апелювання до народного світогляду, але й орієнтацію на народного читача або слухача, i, разом 3 тим, наявність своєрідного очевидця - один із засобів дотримання принципу правдивості" [Янковська, 2017, с. 99]. 
Не викликає застережень жанрове означення "Гордовитої пари" як оповідання-балади [Романишина, 2011, с. 10]. Однак у баладі зазвичай наявний прийом метаморфози - перетворення дівчини на квітку чи пташку тощо. У сюжеті даного твору таких метаморфоз не відбувається. Читач не знає передісторії головних героїв, дія зосереджується на трагічній загибелі молодої пари.

Погоджуємося 3 думкою Ю. Коваліва: "сентименталізм швидше певний умонастрій $з$ характерними ознаками, в якому першорядного значення надавалося почуттям та меланхолійній замріяності" [Літературознавча енциклопедія, 2007, т. 2, с. 381].

Отже, у стилістиці оповідання П. Куліша, на нашу думку, поєднуються елементи романтизму із сентименталізмом. Поділяючи погляд Ліша Сюй, Ж. Янковської, Н. Романишин на твір як на зразок романтичного оповідання, доповнимо, що елементи сентименталізму, відчутні у творі, значно увиразнюють його формальну структуру, збагачують зміст.

\section{СПИСОК ВИКОРИСТАНИХ ДЖЕРЕЛ}

Квітка-Основ'яненко Г. Українські повісті / Г. Квітка-Основ'яненко; упоряд., передм., прим. Л. В. Ушкалова. - Х., 2003. - 352 с.

Куліш П. Твори : у 2 т. / П. Куліш - К., 1989. - 586 с.; Літературознавча енциклопедія : у 2 т. / авт.-уклад. Ю. І. Ковалів. - К., 2007. - Т. 2. - 624 с.

Пахаренко В. Українська література : підруч. для 9-го кл. загальноосвіт. навч. закл. / В. Пахаренко. - К, 2004. - 392 с.

Романишина Н. Баладні оповідання "Максим Гримач" Марка Вовчка та "Гордовита пара" П. Куліша: аналіз в аспекті компаративної генології / Н. Романишина // Укр. л-ра в загальноосвіт. шк. -2011. - № 5. - С. 9-13. - Режим доступу: http://nbuv.gov.ua/UJRN/. - Назва з екрану. - Дата перегляду: 20.03.17.

Сюй Ліша. Образ жінки у малій прозі Пантелеймона Куліша / Ліша Сюй // Укр. літературознавство. - Львів, 2013. - Вип. 77. - С. 177-184.

Сюй Ліша. Художня проза Пантелеймона Куліша у контексті українсько горомантизму : автореф. дис. ... канд. філол. наук : 10.01.01 / Ліша Сюй. - Л., 2015. $-20 \mathrm{c}$.

Янковська Ж. Фольклоризм української літературної прози доби романтизму : дис. ... д-ра філол. наук : 10.01.01, 10.01.07 / Ж. Янковська. - Л., 2017. $-466 \mathrm{c}$.

\section{REFERENCES}

Kvitka-Osnovianenko H. Ukrainski povisti / H. Kvitka-Osnovianenko ; uporiad., peredmova, prymitky L. V. Ushkalova. - Kharkiv, 2003. - 352 s.

Kulish P. Tvory : u 2 т. / P. Kulish. - Kyiv, 1989. - T. 2. - 586 s. 
Literaturoznavcha entsyklopediia : u 2 t. / avt.-ukladach Yu. I. Kovaliv. - Kyiv, 2007. - T. 2. $-624 \mathrm{~s}$.

Pakharenko V. Ukrainska literatura: pidruchnyk dlia 9-ho klasu zahalnoosvitnikh navchalnykh zakladiv / V. Pakharenko. - Kyiv, 2004. - 392 s.

Romanyshyna N. Baladni opovidannia "Maksym Hrymach" Marka Vovchka ta "Hordovyta para" P. Kulisha: analiz v aspekti komparatyvnoi genolohii / N. Romanyshyna // Ukrainska literatura v zahalnoosvitnii shkoli. - 2011. - № 5. S. 9-13. - Rezhym dostupu: http://nbuv.gov.ua/UJRN/. - Nazva z ekranu. - Data perehliadu: 20.03.17.

Siui Lisha. Obraz zhinky u malii prozi Panteleimona Kulisha. Ukrainske literaturoznavstvo / Siui Lisha. - Lviv, 2013. - Vyp. 77. - S. 177-184.

Siui Lisha. Khudozhnia proza Panteleimona Kulisha u konteksti ukrainsko horomantyzmu : avtoref. dys. ... kand. filol. nauk : 10.01.01 / Siui Lisha. - Lviv, 2015. - 20 s.

Yankovska Zh. Folkloryzm ukrainskoi literaturnoi prozy doby romantyzmu : dys. ... dokt. filol. nauk : 10.01.07 / Zh. Yankovska. - Lviv, 2017. - 466 s.

Стаття надійшла до редакції 3.11.19.

S. V. Lenska, Dr Hab, Associate Prof., Poltava V.G. Korolenko National Pedagogical University, Poltava

\section{FEATURES OF POETICS OF SHORT STORY "THE PROUD PAIR" BY P. KULISH}

The short story "The proud pair" by $P$. Kulishtraditionally regarded in the romantic traditions context. But the plot, the main motives, the characters in thestory, the speech organization of the text are convinced that the elements of romanticism and sentimentalism are intertwined in poetry.

At the center of the plot is a tragic love story of Marusya Kovbanivna and Prochor Osaulenko. They were parted due to misunderstanding, then married with others husband and wife, but could not live without each other. The story ends with a tragic interlude.

In the short story traits of sentimentalism are presents, such as depicts exaggerated feelings, events that can move the reader, expresses democracy in the image of heroes, emphasizes nobility in their characters, there is a tragic ending.In the image of Marusya pride is hyperbolized as a leading character trait, and it is presented in the title of the story.

The genre definition of the work is a story ballad. However, the poetics combines the stylefeatures of romanticism and sentimentalism (portraiture of the heroine, description of the wedding).

Keywords: short story, romanticism, sentimentalism, ballad, portrait, narrator, psychologism. 